\title{
CONTAR HISTÓRIAS PARA FORMAR LEITORES: UMA VIAGEM PELA LITERATURA
}

\author{
Fabiano de Oliveira Moraes ${ }^{1}$ \\ Débora Santos Couto ${ }^{2}$
}

Resumo: Caracteriza-se como um estudo qualitativo sobre a formação leitora. Objetiva compreender de que modo o contador de histórias se estabelece como mediador no processo de formação do leitor e de promoção da literatura. Para tanto, apresenta o projeto Viagem pela Literatura (Vitória-ES) e toma por corpus as histórias contadas no CD e no DVD produzidos pelo projeto. Teoricamente, ancora-se no conceito vygotskyano de mediação, pois compreende o referido projeto como uma das instâncias que possibilita a formação do leitor e a democratização lúdica do acesso ao livro e à literatura por meio da mediação do contador de histórias.

Palavras-chave: Contador de histórias. Literatura. Formação do leitor.

\section{TELLING STORIES TO EDUCATE READERS: A TRIP THROUGH LITERATURE}

\begin{abstract}
It is characterized as a qualitative study about reading education. It aims to catch how the storyteller provides him/herself like mediator within the process of reader's education and the literature promotion. Therefore, it presents the project Viagem pela literatura (Vitória-ES) and takes as corpus the stories told in the CD and DVD produced by the project. Theoretically, it is anchored in the Vygotskyan concept of mediation, since it englobes the mentioned project as one of the instances that allows the reader's education and the playful democratization of the access to book and to literature through the storyteller's mediation.
\end{abstract}

Keywords: Storyteller. Literature. Reader's education.

\section{CONSIDERAÇÕES INICIAIS}

O presente trabalho se insere no bojo das discussões sobre a formação leitora. Objetivamos, dentro desse campo de estudo, compreender de que modo o contador de histórias se estabelece como mediador no processo de formação do leitor e de promoção da literatura. Para tanto, apresentamos o projeto Viagem pela Literatura, realizado pela Biblioteca Adelpho Poli Monjardim vinculada à Secretaria Municipal de Cultura de Vitória-ES, e

\footnotetext{
${ }^{1}$ Universidade Federal do Espírito Santo. (professorfabianomoraes@gmail.com)

${ }^{2}$ Universidade Federal do Espírito Santo. (debora.santos2@hotmail.com)
}

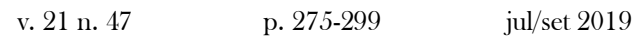


abordamos, notadamente, uma de suas vertentes: as histórias da oratura ${ }^{3}$ e da literatura infantil e juvenil capixaba, contadas no CD e no DVD produzidos no projeto, tomadas como corpus deste trabalho. Optamos por dedicar um olhar mais atento a esses suportes, sabendo que eles dialogam com um conjunto de atividades proposto pelo projeto Viagem pela Literatura, que tem por objetivo democratizar o acesso à literatura, aproximando a criança do texto literário e do objeto livro por meio de abordagens lúdicas.

Consideramos que o projeto em questão se constitui como uma das instâncias mediadoras no processo de formação do leitor, que tem como referência, quando há condições de ocorrer, os ambientes familiares e escolares, como demonstrado na $4^{-}$edição da pesquisa Retratos da Leitura no Brasil 4 (FAILLA, 2016), realizada e coordenada pelo Instituto Pró-livro. Os dados levantados sobre a influência na formação leitora, referentes ao ano de 2015, indicam que os pais, principalmente a mãe, e professores são considerados os maiores influenciadores no processo de desenvolvimento do gosto pela leitura, ressaltando, portanto, a importância da família e da escola na formação leitora. Defendemos, porém, que a formação leitora deva ocorrer em outros espaçostempos, não se restringindo aos ambientes familiar e escolar. $\mathrm{O}$ projeto aqui abordado destaca-se como uma das possibilidades nesse sentido.

Para compreendermos o contexto de idealização do projeto, fonte do corpus deste trabalho, bem como do processo de formação do leitor mediado pela contação de histórias, optamos pelos procedimentos de pesquisa bibliográfica e documental acerca do tema contação de histórias e do projeto Viagem pela Literatura, seguidos da análise do CD e do DVD, tomando por base os referenciais teóricos por nós utilizados.

Perpassa o tema supracitado o conceito de mediação, ancorado teoricamente nas contribuições de Vygotsky (2007), uma vez que compreendemos que o processo de desenvolvimento humano e sua relação com o mundo ocorrem de forma mediada, assim como a formação leitora, processo histórico que se desenvolve em um meio social determinado. Perpassam ainda nosso trabalho as considerações sobre contação de histórias e tradição oral, em sua relação com a arte e com a leitura, de Maia (2007), Abramovich (1984), Chaves (1963), Tahan (1961), Silva (2006), Girardello

\footnotetext{
${ }^{3}$ Segundo SANTOS (2018, p. 108-109), "O conceito de oratura, cunhado pelo linguista ugandês Pio Zirimu, visa dar à expressão oral o mesmo estatuto que tem a expressão escrita”, retornaremos ao conceito mais adiante, desenvolvendo-o.
} 
(2014), Bedran (2010), Barbosa (1997), Yunes (2012), Kastrup (2008), Coelho (1991) e Nascimento (2009).

\section{QUESTÕES TERMINOLÓGICAS}

A primeira questão terminológica a ser apresentada neste artigo diz respeito ao uso da expressão "contação" de histórias, termo que com o decorrer do tempo ganhou força a ponto de hoje ser amplamente utilizado e difundido, fazendo-se presente em artigos, dissertações, teses, livros de especialistas e de escritores literários, além de estar presente, há um bom tempo, na boca dos contadores de histórias.

Partimos da premissa de que um suposto primeiro uso oral desse termo certamente se perdeu no tempo, tenha sido ele pronunciado em algum rincão do nosso país ou em outro país irmão lusófono. Em decorrência disso, os registros escritos tornam-se o caminho mais viável para embasar a nossa busca, posto tal modalidade nos fornecer um maior número de registros materiais da língua.

No que diz respeito ao uso desse termo no âmbito da formação de leitores, o mais antigo registro a que tivemos acesso está presente no artigo Uma ilha rodeada pela literatura infantil, de Fanny Abramovich, publicado na Folha de São Paulo de 8 de abril de 1984, no qual a pesquisadora e escritora refere-se à Biblioteca General José Martí de Havana: "Lá [...] há contação de histórias permanente, oficinas de escrita, de artes plásticas, de mapas, de pesquisa científica, etc.” (ABRAMOVICH, 1984, p. 71, grifo nosso).

No entanto, o mais antigo registro por nós encontrado no qual o termo "contação" denota "narração" (ainda que não esteja formando a composição "contação de: histórias, causos, casos, contos"), encontrado em uma obra literária, está presente em $A$ estória de Lélio e Lina, da autoria de Guimarães Rosa. Na publicação de 1956, no volume único Corpo de Baile, pela José Olympio, Rosa registra o uso do termo "contação":

E quando o J'sé Jórjo começou a querer conversar, Lélio quase concebeu um susto. Nem se sabia como, o homem estava era narrando o caso todo de sua vida, o triste fim dum só acontecido. Era uma contação gostosa e puxada, indo adiante e retornando, 
de ora aos arrancos, de ora mastigando o gaguêjo, e umas esbarradas para pensar melhor, que punham a gente nervoso, e misturando nomes mesmo de pouco se compreender, e explicando passagens sem precisão, mas de que de certo ele, J'séJórjo gostava, com todo tintim. (ROSA, 1956, p. 292-293, grifo nosso).

O termo contação equivale à ação de contar, ao próprio ato de contar histórias, como se pode observar no uso do termo por Pessoa (2011, p. 80): "Elogiou a história e a contação [...]". Para além de referir-se ao ato de contar, o termo contação de histórias também pode referir-se, de modo mais abrangente, à arte de narrar indissociável das técnicas e teorias que lhe subjazem. É possível que as pessoas se refiram, por exemplo, a um livro sobre a arte de contar histórias como sendo um livro sobre contação de histórias. Utilizamos, neste artigo, o termo "contação de histórias" como equivalente a "ato ou ação de contar histórias" e "arte de contar histórias".

Outra questão terminológica presente neste artigo diz respeito ao uso do termo oratura, proposto pelo linguista ugandês Pio Zirimu nas universidades de Makerere em Uganda, na década de 1960, como alternativa à expressão "literatura oral" por apresentar-se mais apropriado para o fim a que se propõe: designar um conjunto de formas verbais orais, artísticas ou não (SANTOS, 2018, p. 108-110), e por ser um termo que aponta, em sua centralidade, para a oralidade, e não para a literatura.

\section{LITERATURA INFANTIL E CONTAÇÃO DE HISTÓRIAS}

Para Coelho (1991), o que hoje é concebido como literatura infantil tem sua gênese na literatura popular oral, a que chamaremos oratura. Nela, "[...] havia a intenção de "passar" determinados valores ou padrões a serem respeitados pela comunidade ou incorporados pelo comportamento de cada indivíduo" (COELHO, 1991, p. 36, grifos da autora).

Nascimento (2009) reitera as considerações de Coelho (1991) ao afirmar que

As origens da literatura infantil/juvenil remontam à literatura popular oral. Esses textos têm como características principais o uso de linguagem verbal oral, a coloquialidade e o recurso à 
gestualidade e à expressão facial. São transmitidas oralmente, recontadas de pessoa para pessoa, de geração em geração. Pela ausência de registro, cada vez que a história é contada e escutada se transforma, sendo, assim, sempre uma paráfrase (NASCIMENTO, 2009, p. 26).

Ainda sobre o assunto, o autor considera que as histórias registradas por escritores como Perrault, Grimm e La Fontaine "[...] não nasceram ligados à cultura escrita, mas sim à oratura” (NASCIMENTO, 2009, p. 27), reafirmando, assim, a importância da contação de histórias e sua estreita relação com a literatura.

Além de transmitir e perpetuar a oratura, a contação de histórias transmite conhecimentos entre gerações, além de entreter e educar (CHAVES, 1963) e estimular a imaginação (GIRARDELLO, 2014).

Mas quem é esse contador de histórias, agente da contação de histórias que propaga e perpetua gêneros da oratura e da literatura?

Em princípio, podemos pressupor que todos, de alguma forma e em algum momento da vida, contarão histórias, sejam elas de origem cotidiana, literária ou da oratura. Há, no entanto, sujeitos reconhecidos socialmente como contadores de histórias, tanto quando presentes em comunidades tradicionais: narradores tradicionais, griôs, detentores das tradições e da história de comunidades e povos, como quando presentes em comunidades urbanas desempenhando essa atividade em teatros, escolas, bibliotecas, hospitais e instituições das mais diversas.

Nesses dois casos de narradores reconhecidos socialmente, há o desenvolvimento de técnicas por parte do contador com o objetivo de potencializar sua arte, o que pode se dar de modo menos sistematizado (no caso das comunidades tradicionais) ou mais sistematizado (no meio urbano), sobretudo para aqueles que praticam essa arte como ofício.

Segundo Otília Chaves, muitos contadores deixam a desejar na aplicação da arte de contar histórias por ignorarem o que é realmente uma história. Para Chaves (1963, p. 6), “[...] como há muito de arte no contar de uma história e como uma história, para ser eficiente, precisa conter certos elementos, obedecer a certos princípios e ter certas características", faz-se necessário “[...] saber o que é uma história, seu valor, suas principais características, os elementos que a constituem e os interesses particulares das diferentes idades" (CHAVES, 1963, p. 8). Para a autora "[...] história é a narrativa verdadeira ou imaginária, 
encerrando uma ação determinada e que apela mais para a emoção do que para o intelecto" (CHAVES, 1963, p. 17, grifo da autora), não devendo ser confundida com os atos de descrever e expor, pois esses visam muito mais a definir e a esclarecer o pensamento a respeito de determinado assunto.

Silva (2006), por sua vez, afirma que em um caminho que narrador e ouvintes percorrem juntos, "[...] o narrador deve estar consciente de que o importante é a história, ele apenas conta o que aconteceu, emprestando vivacidade à narrativa, cuidando de escolher bem o texto e recriando-o na linguagem oral, sem as limitações impostas pela escrita” (SILVA, 2006, p. 11), sendo a história, então, a protagonista.

Daí a importância da seleção do repertório a ser preparado e contado. Deve-se dar atenção especial à etapa de seleção da história, fazendo as pesquisas necessárias para se atender às necessidades da ocasião e aos objetivos que se deseja alcançar. O gosto do contador também deve ser levado em conta. A autora aconselha que sejam escolhidas histórias de que se goste para que se obtenha sucesso ao contá-las. Há de se atentar, também, para a boa construção da história, levando em conta sua escrita, elementos utilizados, linguagem adequada etc.

Após a seleção da história “[...] o narrador deve prepará-la bem, observando os passos formais que a técnica aconselha no preparo de uma história” (CHAVES, 1963, p. 50). A fase de preparação e de estudo da história pode se dar de um modo lúdico, defende Silva (2006). Estudar a "[...] história é, em primeiro lugar, divertir-se com ela, captar a mensagem que nela está implícita e, em seguida, após algumas leituras, identificar os seus elementos essenciais, isto é, que constituem a sua estrutura" (SILVA, 2006, p. 21): introdução, enredo e clímax. A autora destaca o frequente uso de fórmulas de introdução ("Era uma vez", "Numa floresta distante") e de conclusão ("E foram felizes para sempre"), bem como o uso de canções para complementar a narrativa.

Silva (2006) destaca ainda, no âmbito do estudo da história, a escolha da forma de apresentação e dos recursos mais adequados a serem utilizados na hora de contar a história, dentre eles a simples narrativa; a narrativa com auxílio do livro; o uso de gravuras; o uso de flanelógrafo; o uso de desenhos; e a 
narrativa com interferências ${ }^{4}$ do narrador e dos ouvintes, a que chamaremos interação. Somados a esses, destacamos outros recursos apresentados por Barbosa (1997), sejam eles: o uso de livro (não corresponde a ler, mas sim a apresentar o livro e suas ilustrações enquanto se narra); o uso de livros de imagens (livros com sequência imagética sem texto) e o uso de fantoches (acrescentamos a essa categoria o uso de bonecos em geral, inclusive representados por gravuras ou por objetos que "falam”). Bedran (2010, p. 110), por sua vez, destaca o uso de recursos teatrais, tais como iluminação, sonoplastia, figurino, cenário e direção, além do uso de música e adereços.

Ainda no que diz respeito às técnicas empregadas na arte de contar histórias, para Girardello (2014) algumas ações se fazem necessárias à preparação e à apresentação de histórias, tais como: citar a fonte

[...] onde leu ou ouviu cada história e, se possível, falar um pouco sobre o autor ou sobre o contexto em que aprendeu aquela história [...]; ler muitas vezes o texto, procurando enxergar com o olho mental [...]; lê-lo mais um pouco, de preferência em voz alta, para que nossa dicção e nossa voz se familiarizem com os sons, com a sequência precisa das palavras, com a pontuação [...]; investigar as lógicas de organização do texto (GIRARDELLO, 2014, p. 25-27).

\section{CONTAR HISTÓRIAS PARA FORMAR LEITORES}

É Yunes (2012, p. 61) quem nos chama atenção para o fato de que,

por ignorar tanto a história da literatura em suas fontes quanto os estudos contemporâneos de história oral, mas, sobretudo contrariando as mais contundentes experiências sobre a iniciação e o fomento da escrita, há os que vêm ingenuamente propondo que não se conte senão diante de um livro aberto para que não ocorra a desvalorização do objeto-suporte da almejada alfabetização. Mais que isto, a contação tem sido apontada como um retrocesso, um atraso capaz de estimular a preguiça e manter na bem-aventurada comodidade os que mais necessitam esgrimir as letras.

\footnotetext{
${ }^{4}$ No que diz respeito ao termo "interferência" dos ouvintes, proposto por Chaves (1963), Tahan (1961) e Barbosa (1997), optamos por substituí-lo em nosso trabalho pelo termo "interação", mais apropriado e condizente com o nosso referencial teórico.
} 
Segundo a autora, o aprendizado da escrita ou da leitura "[...] é uma questão de entendimento, de construção de sentido, que se sobrepõe à decifração mecânica do código" (YUNES, 2012, p. 61). Para que se almeje a democracia de acesso ao livro é preciso muito mais do que garantir preços baixos (o que também é urgente), é necessário que o potencial leitor tenha acesso à linguagem não por meio de adaptações, reduções e facilitações do texto, mas tornando-o legível pela audição, daí a importância do contador de histórias, pois o gosto pela leitura não tem como caminho a obrigatoriedade do contato físico com a obra, mas sim a afetividade de um contato prazeroso da leitura com os ouvidos, com os olhos, com a voz. "Assim as narrativas sobreviveram para serem escritas. E recontadas” (YUNES, 2012, p. 65).

Nesse sentido, o contador de histórias atua como um atrator de afetos, agindo como uma espécie de atrator caótico por atrair o leitor não para si, "[...] mas para o texto e para os devires que ele comporta” (KASTRUP, 2008, p. 255), por conduzir a “[...] expedição a um mundo desconhecido" (KASTRUP, 2008, p. 256), possibilitando o contato, acompanhando, arrastando consigo. Explorando a potência do momento ao instaurar redes de afetos. O contador de histórias "[...] não diz: ler é bom, é preciso gostar de ler, mas expressa o bom da leitura através de semióticas diversas, a da própria linguagem literária, mas também de rosto e de voz" (KASTRUP, 2008, p. 257).

Além do aspecto afetivo e prazeroso da narração destacado por Kastrup (2008) e por Yunes (2012), é fácil constatarmos que, tanto ao lermos um livro como ao ouvirmos alguém o contando, dá-se o processo de construção de “[...] imagens mentais a partir da palavra, escrita num caso, ouvida no outro. Este é o exercício" (BELLO, 2004, p. 159). Leitura e contação de histórias relacionamse, portanto, por ambas as práticas deflagrarem imagens, promoverem a imaginação. A escuta de histórias, defende Bello (2004, p. 159), "[...] pode tornar-se um encaminhamento para a construção da leitura”.

Como podemos observar, a construção do leitor não se efetiva unicamente no contato com os livros, mas se dá de modo complexo por meio de identificações e gestos, audições e afetos, em meio a práticas escolares e extraescolares, a "[...] histórias contadas e pessoas que dão pertinência à leitura, uma vez que a têm como valor e prática do cotidiano, em horizontes em que liberdade, escolha e opção iluminam o trajeto". (DAUSTER, 2003, p. 110, grifos da autora). Faremos, na seção seguinte, uma breve apresentação do projeto Viagem pela Literatura com o intuito de compreendermos de que modo no CD e no DVD, por nós analisados, o contador de histórias se 
estabelece como mediador no processo de formação do leitor e de promoção da literatura.

\section{O PROJETO VIAGEM PELA LITERATURA: HISTÓRICO E ABRANGÊNCIA}

Com o intuito de levantarmos dados sobre o projeto Viagem pela Literatura, recorremos a um trabalho acadêmico que versa especificamente sobre o tema (ROCHA, 2007). Conforme a autora, o projeto é realizado desde 13 de agosto de 1994 pela Biblioteca Municipal Adelpho Poli Monjardim, localizada no Centro de Vitória-ES. Trata-se de uma ação vinculada à Secretaria Municipal de Cultura de Vitória que tem por objetivos

[...] proporcionar o acesso democrático ao livro e à leitura no
cotidiano de crianças e adolescentes [...] promover a formação de
leitores, a cidadania e a ampliar o público leitor de forma
prazerosa, numa ação sistemática e continuada, por meio das
atividades desenvolvidas por atores, escritores e contadores de
histórias (ROCHA, 2007, p. 33).

Até 2015, faziam parte da equipe do projeto um coordenador, um assistente de produção, um agente de suporte operacional, bibliotecários da biblioteca municipal, além de atores, escritores e contadores de histórias, divididos em diferentes regimes de contratação de trabalho. Ainda no ano de 2018, as atividades do projeto contaram, para além dos recursos disponibilizados pela Secretaria Municipal de Cultura, com recursos oriundos do Prêmio Boas Práticas e Inovação em Bibliotecas Públicas/2014, via edital do Sistema Nacional de Bibliotecas Públicas (SNBP) do Ministério da Cultura (MinC). Também em 2018, o projeto foi premiado na categoria Oralidade da $2^{a}$ edição do Prêmio Ricardo Oiticica, promovido pelo Instituto Interdisciplinar de Leitura (iiLer) da PUC-Rio e a Cátedra UNESCO de Leitura.

As atividades do projeto são realizadas em vários bairros do município de Vitória, em locais como a Biblioteca Municipal, escolas municipais, parques, praças, centros comunitários e museus. $\mathrm{O}$ agendamento de sua realização se dá a partir de uma visita em que se verificam as condições de espaço físico e na qual se efetiva uma parceria com a comunidade para divulgação e conscientização sobre a importância da ação (ROCHA, 2007). 
As atividades do projeto, segundo ordem cronológica de sua criação, são as seguintes: Viver o Livro ao Vivo e em Cores (desde 1994), Contador de Histórias (desde 1994), Encontro com o Escritor (desde 1994), Caixa-Estante (desde 2002), Oficina de Contadores de Histórias (desde 2006), Oficina de Artes (desde 2008), Círculo de Leitura (desde 2008), Oficina de Poesia (desde 2012), Sarau Poético (desde 2012), Leitura no Parque/Praça (desde 2013), distribuídas no decorrer do ano e realizadas em diferentes locais com o intuito de atender a diferentes públicos e bairros do município.

Das oficinas de contadores de histórias oferecidas pelo projeto a partir de 2006, surgiu, em 2009, o Grupo Chão de Letras (sob a supervisão da coordenação do projeto), vertente do projeto que mantém suas atividades de forma voluntária e se apresenta nas atividades promovidas pelo projeto, inclusive interpretando histórias no CD e no DVD.

No que diz respeito à seleção das histórias apresentadas nas atividades, cada contador de histórias convidado a participar do projeto monta seu próprio repertório, atentando, a cada apresentação, para as particularidades da faixa etária do público atendido. Os repertórios são compostos por contos, fábulas, lendas, textos literários, poemas, dentre outros gêneros.

Considerando que o projeto é iniciativa de uma biblioteca municipal capixaba, buscamos saber em que medida há uma preocupação maior em se trabalhar com a diversidade de histórias escritas por autores capixabas, ou que apresentem temáticas ou elementos culturais do Estado. Essa preocupação se mostrou mais evidente no material produzido em formato de CD e DVD, composto majoritariamente por textos de autores capixabas.

Tomamos por foco em nosso trabalho as gravações das narrativas do CD e do DVD em razão desses dialogarem diretamente com três ações do projeto: com o Encontro com o Escritor, na medida em que as histórias gravadas se originam principalmente de obras de autores capixabas, a maioria dos quais se fez e continua se fazendo presente nessa atividade promovida pelo projeto; com a atividade Contador de histórias, pois grande parte dos contadores de histórias presentes no CD e no DVD se apresentou ou ainda se apresenta nessa atividade; e, por fim, com a Caixa-Estante, pois parte dos livros de onde provêm as histórias gravadas encontra-se no acervo da estante ou da Biblioteca Municipal Adelpho Poli Monjardim. Ademais, exemplares do CD e do DVD se fazem presentes em escolas da rede pública municipal de ensino, além de constituírem referência para apresentações de histórias nas ações do projeto. 
Tais mídias congregam e potencializam, portanto, interações promovidas pelo projeto entre contadores de histórias, ouvintes, escritores, leitores e livros.

\section{CORPUS}

Compõem o corpus do nosso artigo as gravações ${ }^{5}$ das histórias no CD e no DVD do projeto Viagem pela Literatura. Buscamos descrevê-las resumidamente, categorizando-as a partir dos recursos utilizados nas contações e em sua relação com a oratura e com a literatura capixaba.

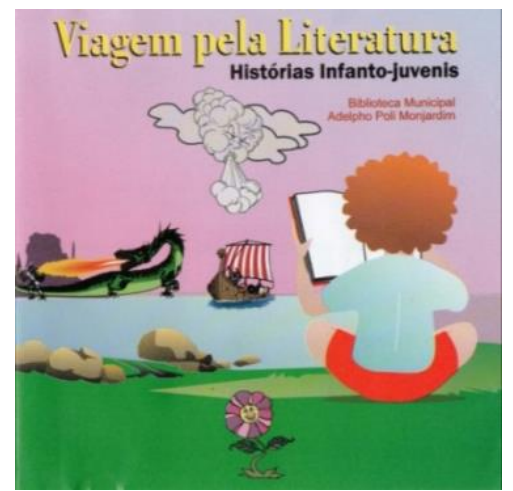

Figura 1 - Capa do CD Viagem pela Literatura: Histórias Infanto-juvenis. Biblioteca Municipal Adelpho Poli Monjardim. Fonte: Viagem (2007).

O CD (Figura 1), produzido no ano de 2007, é composto por 12 faixas: Leve como a folha (5min 44s), livro de Francisco Aurélio Ribeiro contado por Clara Maria Monteiro; $O$ fantasma do convento (4min 53s), lenda da oratura capixaba publicada em livro homônimo e contada por Rodrigo Campanelli; Dom sapo comedor de mosquitos/A linguagem dos bichos (4min 38s), publicados por Hermógenes Lima Fonseca e contados por Bete Broetto; $A$ onça e a raposa (5min 21s), fábula da oratura africana recontada por Flávia D’Ávila; A menina e o anjo (6min 09s), texto publicado no livro Contar

\footnotetext{
${ }^{5}$ Concentramos nossa análise nos recursos utilizados para contar histórias, presentes nessas gravações (em áudio no CD e em audiovisual no DVD), nosso foco não estará, portanto, nos cortes e nas edições, nos ângulos de filmagem, nos efeitos de som, e nos demais códigos próprios das produções de áudio e de audiovisual.
} 
histórias: a arte de brincar com as palavras de Fabiano Moraes contado pelo mesmo; João, o botão (6min 23s), livro de Elizabeth Martins contado por João Vitor Lemos Batista; Crinquinim e o Convento da Penha (9min), livro de Reinaldo Santos Neves contado por Silvana Sampaio; Xênia, xereta (6min 14s), livro de Luiz Sérgio Quarto contado por Margareth Maia; Era uma vez um lugar... Juçará (5min 41s), livro de Marilena Soneghet contado por Ananda Rasuck; Mocó, príncipe como ele só (6min 50s), texto e contação de Fernando Soledade; A casa que andava (6min 32s), livro de Maria Helena Hess Alves contado por Marinalda Falcão Loureiro; e $A$ pedra dos olhos (4min 48s), lenda publicada por Adelpho Poli Monjardim no livro O Espírito Santo na lenda, na história e no folclore, adaptada por Leonardo Monjardim e contada por Rogério Fraga.

Das doze histórias contadas, dez foram publicadas em livros da autoria de escritores capixabas. Desses dez autores capixabas, oito participaram da atividade Encontro com o Escritor. Entre os outros dois, ambos falecidos, um dá nome à Biblioteca Pública a que se vincula o projeto: Adelpho Poli Monjardim e o outro foi homenageado em ações do projeto: Hermógenes Lima da Fonseca. Todas as faixas são narradas por contadores de histórias que participaram, dentre outras ações do projeto, das atividades Contador de histórias ou Encontro com o escritor (nessa última, desde 2001 o escritor passou a ser acompanhado por um contador de histórias que narra histórias de seus livros). Ademais, grande parte dos livros contados encontra-se disponível na Caixa-Estante e/ou no acervo da Biblioteca Municipal Adelpho Poli Monjardim, favorecendo a tomada por empréstimo ou a leitura in loco.

Em consonância com as considerações de Silva (2006), Barbosa (1997), Bedran (2010) e Girardello (2014), ao explicitarem os recursos de que o contador dispõe ao exercer a arte de contar histórias, foi possível, ao longo da análise do material, percebermos o emprego de alguns desses recursos pelos contadores ao contarem determinadas histórias, adequando os recursos de forma a potencializar o resultado final da contação.

Para além da voz, recurso primordial da narração da história, que ainda conta com as diferenciações feitas pelos contadores para destacar as falas dos personagens e suas emoções, outros recursos sonoros utilizados na contação de todas as histórias se tornam grandes aliados para tornar mais dinâmicas as narrativas. Tais recursos se apresentam no formato de canções como parte do enredo ao longo da história, ocorridos em três das histórias: em duas delas, parte da história é musicada e cantada, enquanto na outra, duas cantigas populares construídas sobre uma mesma melodia (Nessa rua tem um bosque e 
Se essa rua fosse minha) são cantadas como parte da fala dos personagens e do narrador. Em nove faixas, a história se inicia com uma música instrumental, em uma delas com a melodia da cantiga popular $O$ meu chapéu tem três pontas e nas outras com execução de melodias por nós não identificadas. Em duas outras histórias contadas, o recurso da música instrumental surge para indicar a passagem do tempo. Os recursos de sonoplastia remetem ainda a elementos como o som da água, do coaxar de sapos, do som de insetos e da chuva em uma das histórias, ou ao toque do sino e ao vento em outra. Na sonoplastia foram utilizados instrumentos como casaca (reco-reco capixaba utilizado no folguedo Congo), caxixi, teclado, viola caipira, violão, entre outros recursos de sonoplastia do estúdio de gravação, enriquecendo, desse modo, as narrativas.

As frases ou fórmulas de introdução, como "Era uma vez" e "Há muito tempo atrás", restringem-se a quatro das histórias presentes no CD. Nos outros contos encontramos introduções mais elaboradas ou específicas: "Numa manhã sonolenta de abril", "Zezinho morava num casebre no alto do morro", "Bem, eu não sei quem é que começou essa confusão", "João era um botão que queria ser mais que um botão", "Será que você adivinha o lugar de que estou falando?", "Esta é a história de Xênia”, "Tudo começou ao voltar do meu trabalho" e "Em Jucutuquara, bairro de Vitória".

O uso de fórmulas de encerramento se limita a duas histórias: "Todos viveram felizes para sempre" e "É assim que me contaram e é assim que agora lhes contei”. Nas outras histórias são encontrados os encerramentos: "Eram as lembranças das lesminhas", "Zezinho ficou todo sorridente ao ver tanta sabedoria vinda de seu pai", "Para o meu amor passar", "Sentia que era mesmo de um cachorro, o focinho", "Morro com vento, e agora com Convento", "Eita, Xênia mexeriqueira”, "Plante a vida!", "Ele ainda era sapo, mas tinha agora ao seu lado, uma sapinha princesa", "Virou uma casa fantasma", "Por causa de sua imponente e magnífica beleza”. 


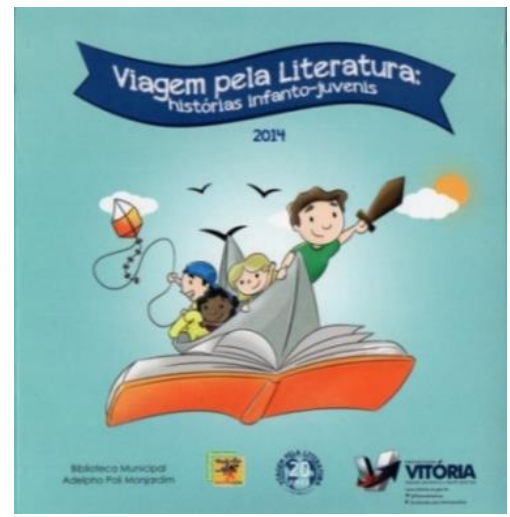

Figura 2 - Capa do DVD Viagem pela Literatura: Histórias Infantojuvenis. Biblioteca Municipal Adelpho Poli Monjardim. Fonte: Viagem, 2014.

Já o DVD (Figura 2), produzido no ano de 2014, é composto por treze faixas: A bailarina cor de rosa (3min), livro de Elizabeth Martins contado por Sandra Freitas; A baleia jubarte (7min 54s), livro de Rodrigo Campaneli contado pelo mesmo; $A$ casa rosa (2min 56s), livro de Silvana Pinheiro contado por Fernando Soledade; Crinquinim e a puxada de mastro (4min 50s), adaptação do livro homônimo de Reinaldo Santos Neves contada por Victor Barros e João Vitor Lemos; Era uma vez uma chave (3min 10s), livro de Francisco Aurélio Ribeiro contado por Norma Helena Silva Agrizzi; $O$ gato verde (5min $35 \mathrm{~s}$ ), livro de Ilvan Filho contado por Alixandra Dantas (Boneca Lili); História do barbagato (7min 03s), livro de Luiz Guilherme Santos Neves contado por Tiana Magalhães; Joãozinho, o marinheiro azul (4min 34s), livro de Marta Samor contado pela mesma; A lenda do Caparaó (7min 18s), lenda da oratura capixaba contada por Ananda Rasuck e William Rodrigues; $O$ menino e a atiradeira (4min 10s), livro de Fabiano Moraes contado por Cleyton Passos; Pássaro de fogo (3min 06s), do livro Lendas capixabas em versos, publicado e contado por Silvana Sampaio; Poema do livro Circo Universal (2min 14s), de Raimundo Carvalho e Ivan Luis B. Mota, contado por Gab Kruger e Shita Yamashita; e Vampirinho em versos (2min 03s), do livro De cabelo em pé de Neusa Jordem Possatti contado por Alzira Bossois.

Todos os autores das doze histórias provenientes de livros, gravadas no DVD, estiveram presentes em atividades de Encontro com o Escritor do projeto Viagem pela Literatura. Do mesmo modo todos os contadores participantes da mídia estiveram presentes nas atividades Contador de histórias ou Encontro com o escritor, dentre outras ações desenvolvidas pelo projeto. 
Alguns dos livros apresentados nos vídeos encontram-se disponíveis para empréstimo na Caixa-Estante e/ou no acervo da Biblioteca Municipal Adelpho Poli Monjardim.

Assim como no material produzido em formato de CD, nas histórias que compõem o DVD, que conta também com o fator visual, foram empregados recursos diferenciados (SILVA, 2006; BARBOSA, 1997; BEDRAN, 2010; GIRARDELLO, 2014) em cada uma das histórias, sendo que alguns deles foram utilizados por mais de um contador ou duplas de contadores. Apresentamos, a seguir, os recursos utilizados no sentido de apontarmos para a diversidade de recursos de apresentação de histórias dos quais os contadores lançam mão ao se estabelecerem como mediadores no processo de formação do leitor e de promoção da leitura nas gravações do DVD.

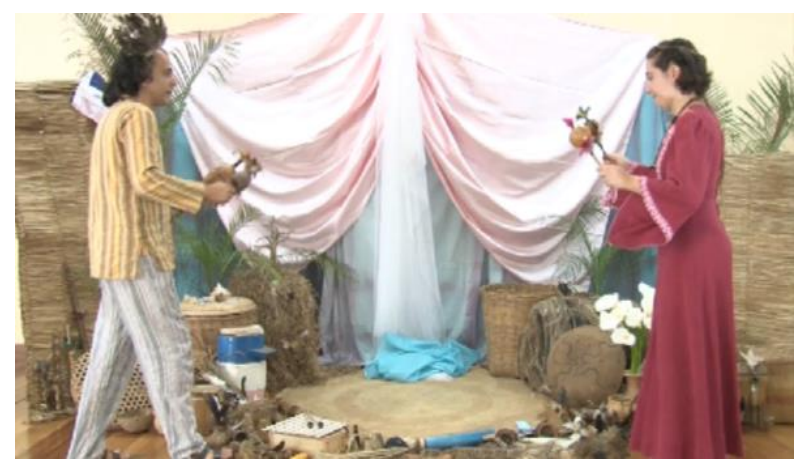

Figura 3 - Contação baseada na história A Lenda do Caparaó (conto popular de tradição oral). Contadores Ananda Rasuck e William Rodrigues. Fonte: Viagem (2014).

A música, cantada e tocada, esteve presente em pelo menos duas histórias. Em uma, fez-se o uso de instrumentos musicais: casaca, violão, tambor e violino para acompanhar canções. Em outra, os contadores fizeram uso de chocalhos indígenas, pios, flauta, casaca e xilofone, para criar ritmo, melodia ou acompanhar canto, e para indicar passagem de tempo, canto dos pássaros, som do vento e movimento de asas (Figura 3). Não foram reproduzidas músicas ou canções previamente gravadas; quando usadas, elas foram cantadas e tocadas ao vivo, no início, ao longo, ou no desfecho da contação. Em uma das histórias fazse uso, no início e no final da gravação, de uma caixinha de música com a melodia de Für Elise, de Beethoven. 
No que tange às fórmulas de introdução, apenas quatro, das treze histórias, fizeram uso desse recurso: "Quem gosta de história aqui?", "Todos os dias" e "Era uma vez" (em duas delas). Os outros contos apresentam introduções menos universais: "O circo chegou", "Na larga rua da amizade fica a casa rosa", "Lá estava o Crinquinim comendo carambola", "Ele era um gato como outro qualquer", "Barbagato era um gato muito velho", "Quando chegaram as grandes canoas", "ÊE, mundo velho sem porteira", "No sutil limite entre a mitologia e a história" e "Era noite de lua cheia".

Já as frases de encerramento se restringem a duas histórias: "E agora essa história acabou, chegou ao fim" e "Puderam viver felizes para sempre", além das finalizações menos comuns: "E acabou-se a lenda do pássaro de fogo", "Não fosse assim, não seria tão admirada", "Onde já se viu cachorro comer carambola?", "Ficou roxa de felicidade", "Foram amigos pelo resto de suas vidas", "E para que servem os gatos?", "Para onde o vento levar", "Ofertamos a todos vocês a nossa alegria", "Então, quebrei minha atiradeira", "Acham que a Lua é a cara branca de um palhaço divino" e "Você tá vendo aquele poste ali? Eu não vi”.

O uso de fantoches também foi um recurso utilizado por alguns contadores. Uma das histórias foi narrada pelo próprio fantoche, caracterizando-se muito mais como teatro de bonecos do que como contação de histórias com uso de bonecos. Em outras duas, há a presença do contador e dos bonecos feitos com gravuras, no formato de imagens fixadas em hastes de madeira (um gato, um sapo e um jacaré em uma das narrativas, e uma sereia e um pássaro na outra), utilizados ao longo da narrativa (Figura 4).

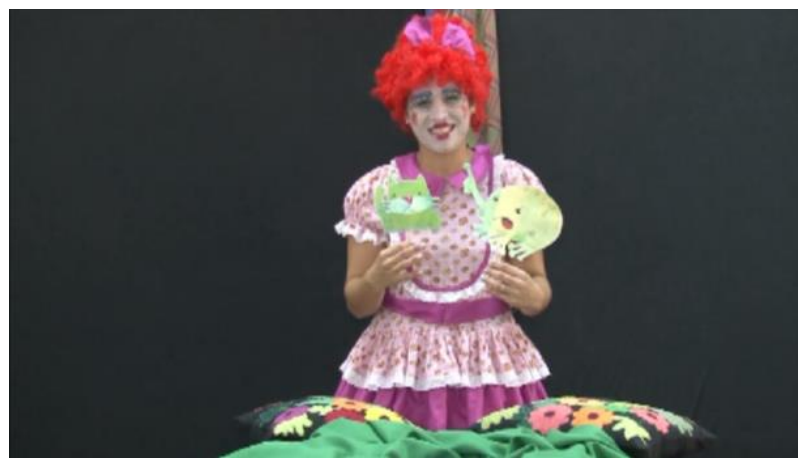

Figura 4 - Contação baseada no livro O gato verde, de Ilvan Filho. Contadora Alixandra Dantas (Boneca Lili). Fonte: Viagem (2014). 
O objeto livro foi exibido como fonte no início e no fim de uma das histórias, sem ser, de fato, utilizado durante a contação. (Figura 5).

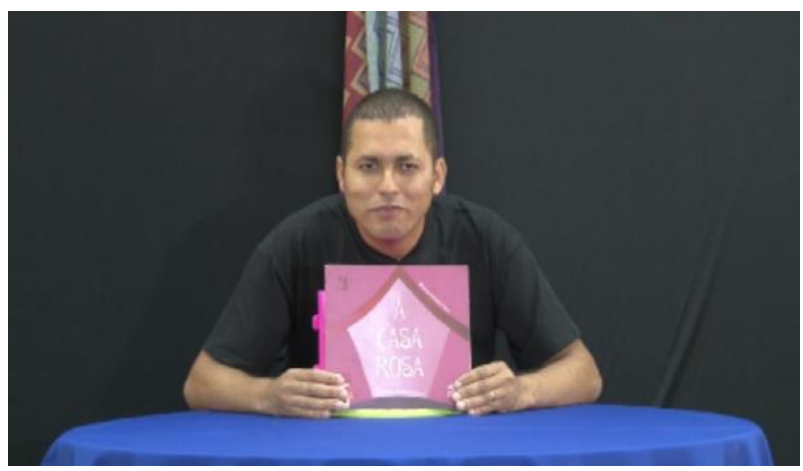

Figura 5 - Contação baseada no livro A casa rosa, de Silvana Pinheiro.

Contador Fernando Soledade. Fonte: Viagem (2014).

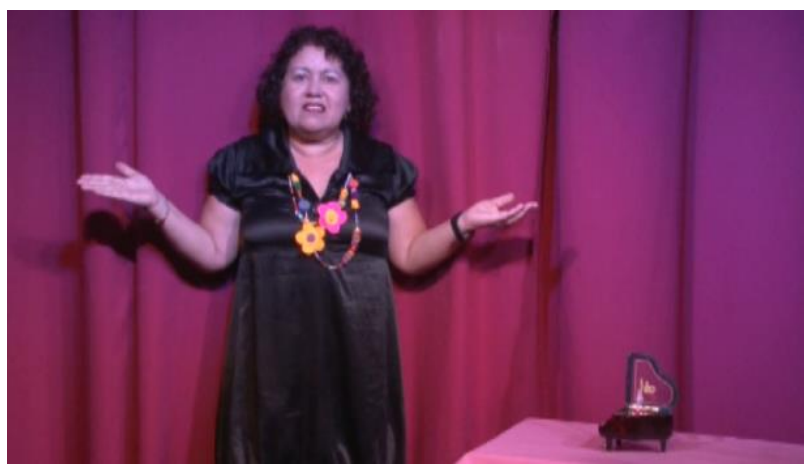

Figura 6 - Contação baseada no livro A bailarina cor de rosa, de Elizabeth Martins, ilustrado por Cleria Rachel. Contadora Sandra Freitas. Fonte: Viagem (2014).

No que diz respeito ao cenário, uma das histórias foi contada como teatro de fantoches, com um painel como cenário e um boneco que contou toda a história. Em quatro das histórias narradas, optou-se por não se usar elementos cenográficos que chamassem a atenção, que não a utilização de um ou outro objeto ou adereço que auxiliasse no desenvolvimento da contação, como, por 
exemplo, uma mesa e uma caixinha de música (Figura 6) e uma casinha rosa de brinquedo (Figura 5). Quatro das gravações foram realizadas com uso de cenário mais elaborado, com elementos como plantas, tecidos, pufs, esteiras, cestos, tapete (Figura 3). Os outros quatro vídeos foram feitos em palco de teatro (Figuras 7 e 8), sem, no entanto, se fazer uso de cenário elaborado, e com a presença de público.

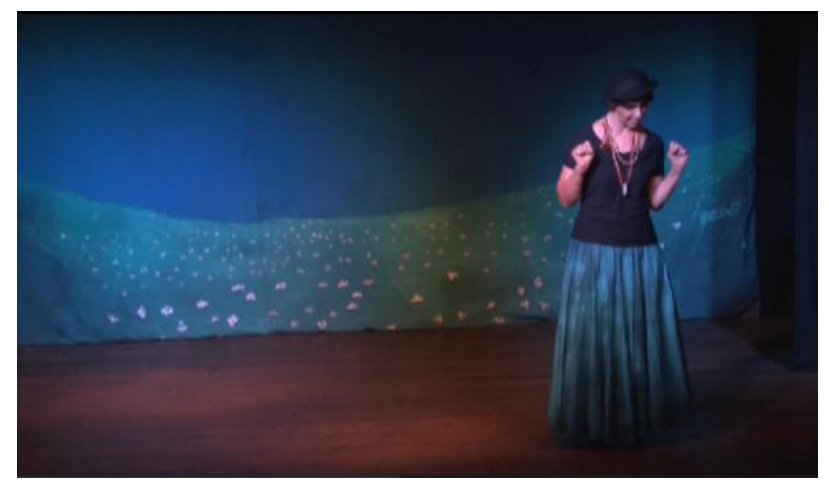

Figura 7 - Contação baseada no livro História de barbagato, de Luiz Guilherme Santos Neves. Contadora Tiana Magalhães. Fonte: Viagem (2014).

Em apenas uma das gravações, o contador de histórias fez uso do recurso da interação com os ouvintes, que aqui não será analisada no que diz respeito às reações do público presente no processo de gravação, mas considerado como recurso de contação de histórias a compor a diversidade de apresentações contemplada na mídia analisada e a estabelecer o contador de histórias em seu papel de mediador. Nessa mesma história, o contador utiliza uma mala de onde retira objetos, materiais representando lixo e adereços de cabeça em forma de animais marinhos como recursos a auxiliarem no desenvolvimento da narração (Figura 8). 


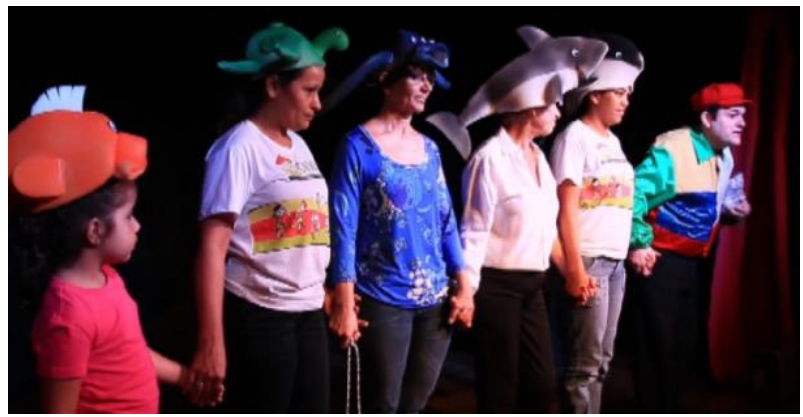

Figura 8 - Contação baseada no livro A baleia jubarte, de Rodrigo Campaneli. Contador: Rodrigo Campaneli. Fonte: Viagem (2014).

Além da variedade de ambientes elencados para a contação, os figurinos utilizados também deram tom a cada história. Os contadores optaram ora por usar roupas neutras, na maioria de cor preta, no sentido de dar mais ênfase à história (Figura 5), ora por usar figurinos mais elaborados, como, por exemplo, fantasia de boneca (Figura 4) ou de maquinista (Figura 8).

A partir da análise do corpus pudemos detectar encontros potentes do milenar com o moderno. As práticas tradicionais da contação de histórias aliamse ao viés tecnológico. As mídias produzidas se apresentam não como uma substituição de práticas já consolidadas de contação de histórias, sobrepujandoas, mas como um recurso adicional a se recorrer para perpetuar a arte, para promover a leitura e para formar leitores.

Insistir na importância que manteve o manuscrito após a invenção de Gutemberg, é uma forma de lembrar que as novas técnicas não apagam nem brutal nem totalmente os antigos usos, e que a era do texto eletrônico será ainda, e certamente por muito tempo, uma era do manuscrito e do impresso (CHARTIER, 2002, p. 8).

\section{DOS PROCESSOS DE MEDIAÇÃO}

Com base no que apresentamos até aqui, podemos considerar que no projeto Viagem pela Literatura, contadores de histórias, por meio de áudios, vídeos, apresentações, suportes, vozes, gestos, recursos e espaços, atuam como mediadores do processo de formação leitora. 
Consideramos a formação leitora e a promoção da literatura no acesso das crianças ao CD e ao DVD, no que diz respeito ao potencial de tais mídias nesse processo, quando utilizadas por professores das escolas públicas ou como referência para apresentações nas atividades promovidas pelo projeto. Por essa razão não analisamos as reações das crianças presentes nas gravações, mas sim os recursos escolhidos pelos contadores ao se constitúrem como mediadores no âmbito da mídia em questão.

Para Vygotsky (2007), precursor da Teoria Histórico-Cultural, a relação com o mundo não ocorre de forma direta, mas sim mediada, de forma simbólica, pelos signos e instrumentos. Nessa perspectiva, a linguagem, considerada como própria do ser humano, faz a mediação dos indivíduos entre si e desses com o meio. É, portanto, na troca com o outro, nas interações sociais ocorridas em um meio histórico e social, que o ser humano se desenvolve e se forma. Para ele

\begin{abstract}
Desde os primeiros dias do desenvolvimento da criança, suas atividades adquirem um significado próprio num sistema de comportamento social e, sendo dirigidas a objetivos definidos, são refratadas através do prisma do ambiente da criança. $\mathrm{O}$ caminho do objeto até a criança e desta até o objeto passa através de outra pessoa. Essa estrutura humana complexa é o produto de um processo de desenvolvimento profundamente enraizado nas ligações entre história individual e história social (VYGOTSKY, 2007, p. 19-20).
\end{abstract}

A contribuição do teórico com este trabalho se dá por entendermos que, por meio das interações sociais a criança tem sua relação com os bens culturais, tal como o livro, mediada, sendo essas interações favoráveis para o seu desenvolvimento, aprendizado, e, portanto, para a sua formação leitora.

A partir dessa concepção, nas atividades em que a criança tem a oportunidade de manusear um livro, folhear suas páginas e admirar as ilustrações ali contidas, como proporcionado nas ações Contador de Histórias, Encontro com o escritor e Caixa-Estante, mesmo que a criança ainda não consiga propriamente ler o texto escrito ali presente, tal movimento já se configura importante para a sua formação e desenvolvimento. Não se faz necessário esperar, portanto, que a criança se encontre alfabetizada para lhe oportunizar as primeiras experiências com obras literárias. Conforme Maia, “[...] no processo de interação com o livro de literatura, mesmo que ainda não decifrando o código escrito, a criança constrói significados a partir de um referencial que lhe é muito particular: a própria experiência” (MAIA, 2007, p. 
78), cabendo à mediação realizada assumir um caráter de diálogo e constante troca, e não arbitrário.

No material pesquisado, as produções se dão de modo a potencializar interações lúdicas entre adultos e crianças, criando toda uma atmosfera no sentido de favorecer tantas e mais possíveis interações com diferentes vertentes, lançando mão de espaços que dispõem de elementos que visam a criar um campo fértil para a produção de sentidos que a experiência possa favorecer. As diferentes manifestações artísticas de que o projeto faz uso tendem a potencializar significativamente essas experiências nas interações promovidas nas escolas na ocasião da apreciação do CD e do DVD em sala de aula, ou nas atividades do projeto que envolvem o uso da mídia ou que a tomem como referência.

Atentamos ainda para a interação entre sujeito e meio. Uma vez que o projeto realiza suas atividades em espaços públicos, como bibliotecas, parques, praças, escolas, centros comunitários e museus, entende-se que há um movimento de apropriação desses espaços pelo sujeito e o reconhecimento de sua participação ativa como cidadão pertencente àquele espaço.

O CD e o DVD, dialogando diretamente com três atividades do projeto, potencializa e concentra suas ações. Tal como ocorre na dinâmica da atividade Contador de Histórias, nas gravações a narrativa oral carrega consigo toda uma bagagem histórica, que, ao perpetuar uma prática antiga, fascina e ao mesmo tempo promove a troca de experiências e vivências de forma lúdica, bem como o estímulo à leitura e o resgate da oralidade. Do mesmo modo como se dá no Encontro com o Escritor, nas histórias gravadas, a criança é apresentada a livros de escritores locais (muitas vezes vistos, estes últimos, como distantes do alcance do público), aproximando-se de produções literárias a partir de experiências que podem promover produções de sentido e de significado mediadas pelos afetos presentes na apresentação do contador de histórias que conta cada livro. Os livros da Caixa-Estante e do acervo da Biblioteca Adelpho Poli Monjardim, consequentemente, tendem a ser buscados a partir das redes de afetos que escritor e contador, como atratores de afetos (KASTRUP, 2008), por meio do CD e do DVD, instauram não em direção a si, mas em direção ao livro, pois eles não dizem que ler é bom, que é preciso gostar de ler, mas expressam como é bom ler e escrever por meio de sua linguagem literária, de seu rosto, de sua voz. 


\section{CONSIDERAÇÕES FINAIS}

De acordo com Rocha (2007) "Observou-se ser preciso adquirir em maior número a bibliografia dos autores capixabas, pois após os encontros com os escritores, houve interesse do público participante em ler suas obras" (ROCHA, 2007, p. 49). CD e DVD, ao contemplarem as obras desses escritores, potencializam esse interesse. Vale lembrar que, além de se fazerem presentes em todas as escolas da rede pública municipal, as histórias de tais mídias constituem referência para contadores de histórias que as multiplicam por meio de sua arte.

Ao promover oportunidades diferentes de interações ocorridas entre contadores de histórias, ouvintes, escritores e livros, o projeto Viagem pela Literatura cumpre um papel imprescindível na instrumentação das práticas de formação de leitores.

Para o público, por outro lado, acreditamos que a experiência adquirida pela promoção de leitura efetivada por meio da mediação de contadores de histórias junto ao público atendido pelo projeto e junto a estudantes das escolas da rede, se dê em diferentes instâncias: no estímulo ao faz de conta, à imaginação, à criatividade, na oportunização do acesso democrático ao livro, à leitura, aos acervos, na formação lúdica e prazerosa de leitores, e na promoção da oratura capixaba e da literatura produzida no estado do Espírito Santo

Esperamos que a presente pesquisa suscite futuras investigações que se debrucem sobre os usos do CD e do DVD na sala de aula e nas interações efetivadas por meio do projeto, ações a que apenas aludimos por meio das hipóteses nascidas durante a elaboração deste trabalho que teve por foco identificar os recursos de contação de histórias presentes nessas duas mídias como instrumentos potentes utilizados pelos contadores de histórias ao se efetivarem como mediadores no processo de formação do leitor e da promoção da literatura, e que, acreditamos, poderá ser tomado como ponto de partida para novas incursões sobre os processos de mediação na formação do leitor, no âmbito do uso de tais mídias. 


\section{REFERENCIAS}

ABRAMOVICH, Fanny. Uma ilha rodeada pela literatura infantil. Folha Ilustrada. Folha de São Paulo, p. 71, 8 abr. 1984.

BARBOSA, Reni Tiago Pinheiro. Pontos para tecer um conto. Il: Virgílio Velozo. Belo Horizonte: Editora Lê, 1997.

BEDRAN, Beatriz Martini. Ancestralidade e contemporaneidade das narrativas orais: A arte de cantar e contar histórias. 2010. Dissertação (Mestrado em Ciência da Arte). Programa de Pós-Graduação em Ciência da Arte, Universidade Federal Fluminense, Niterói, 2010.

BELLO, Sérgio. Por que devemos contar histórias na escola? In: GIRARDELLO, Gilka (Org.). Baús e chaves da narração de histórias. Florianópolis: SESC/SC, 2004. p. 156-163.

BUSATTO, Cléo. Paiquerê Piquiri Fiietó, um experimento com as linguagens. In.: PRIETO, Benita (Org.). Contadores de histórias: um exercício para muitas vozes. Rio de Janeiro: [s. n.], 2011. p. 101-103.

CHARTIER, Roger. Os desafios da escrita. São Paulo: Unesp. 2002.

CHAVES, Otília O. A arte de contar histórias. Biblioteca de Educação Religiosa. Confederação Evangélica do Brasil. 3. ed. Rio de Janeiro. 1963.

COELHO, Nelly Novaes. Literatura infantil: teoria, análise, didática. 5. ed. Editora Ática. São Paulo. 1991.

DAUSTER, Tânia. Jogos de inclusão e exclusão sociais: sobre leituras e escritores urbanos no final do século XX no Rio de Janeiro. In: YUNES, Eliana e OSWALD, Maria Luiza (Orgs.). A experiência da leitura. São Paulo: Loyola, 2003. p. 91-116.

FAILLA, Zoaira (Org.). Retratos da leitura no Brasil 4. Rio de Janeiro: Sextante, 2016.

GIRARDELLO, Gilka. Uma clareira no bosque: Contar histórias na escola. Campinas, SP: Papirus. 2014.

KASTRUP, Virgínia. Sobre livros e leitura: algumas questões acerca da aprendizagem em oficinas literárias. In: KASTRUP, Virgínia; TEDESCO, 
Silvia; PASSOS, Eduardo (Orgs.). Políticas da cognição. Porto Alegre: Sulina. 2008. p. 241-266.

MAIA, Joseane. Literatura na formação de leitores e professores. São Paulo: Paulinas. 2007.

NASCIMENTO, José Augusto de A. Literatura infantil e cultura hipermidiática: relações sócio-históricas entre suportes textuais, leitura e literatura. Dissertação de Mestrado (Mestrado em Letras). Programa de PósGraduação em Estudos Comparados de Literaturas de Língua Portuguesa. Universidade de São Paulo, São Paulo, 2009.

ROCHA, Elizete Terezinha Caser. Leitura e cidadania: a experiência de Goiabeiras. Monografia de Especialização. Universidade Federal do Espírito Santo. Vitória, ES. 2007.

ROSA, João Guimarães. Corpo de baile. Rio de Janeiro: José Olympio, 1956.

SANTOS, Boaventura de Sousa. O fim do império cognitivo: a afirmação das epistemologias do Sul. Coimbra: Grupo Almedina, 2018.

SILVA, Maria Betty Coelho. Contar histórias: uma arte sem idade. Editora Afiliada. 2006.

TAHAN, Malba. A arte de ler e contar histórias. 3. ed. Rio de Janeiro: Conquista, 1961.

VIAGEM pela Literatura: histórias infanto-juvenis. Biblioteca Municipal Adelpho Poli Monjardim. Secretaria Municipal de Cultura. Prefeitura Municipal de Vitória-ES, 2007. 1 CD.

VIAGEM pela Literatura: histórias infanto-juvenis. Biblioteca Municipal Adelpho Poli Monjardim. Secretaria Municipal de Cultura. Prefeitura Municipal de Vitória-ES, 2014. 1 DVD.

VYGOTSKY, Lev Semyonovich. A formação da mente: o desenvolvimento dos processos psicológicos superiores. 7. ed. São Paulo: Martins Fontes, 2007.

YUNES, Eliana. Contar para ler: A arte de contar histórias e as práticas de leitura. In: MORAES, Fabiano; GOMES, Lenice (Orgs.). A arte de encantar: o contador de histórias contemporâneo e seus olhares. São Paulo: Cortez Editora, 2012. p. 59-77. 
Recebido em: 30/10/2018 Aprovado em: 03/06/2019 